\title{
BMJ Open The Danish HIV Birth Cohort (DHBC) - a nationwide, prospective cohort
}

\author{
Nina Weis (D) , , ${ }^{1,2}$ Terese L Katzenstein, ${ }^{3}$ Mathilde Ørbæk (D) , ${ }^{1}$ Merete Storgaard, ${ }^{4}$ \\ Gitte Pedersen, ${ }^{5}$ Isik S Johansen, ${ }^{6}$ Ellen Moseholm (i) ${ }^{1}$
}

To cite: Weis N, Katzenstein TL, Ørbæk M, et al. The Danish HIV Birth Cohort (DHBC) - a nationwide, prospective cohort. BMJ Open 2021;11:e044565. doi:10.1136/ bmjopen-2020-044565

- Prepublication history for this paper is available online. To view these files, please visit the journal online (http://dx.doi org/10.1136/bmjopen-2020044565).

Received 09 September 2020 Accepted 02 June 2021

Check for updates

(C) Author(s) (or their employer(s)) 2021. Re-use permitted under CC BY-NC. No commercial re-use. See rights and permissions. Published by BMJ.

${ }^{1}$ Department of Infectious Diseases, Copenhagen University Hospital, Hvidovre, Denmark

${ }^{2}$ Department of Clinical Medicine, Copenhagen University, Copenhagen, Denmark

${ }^{3}$ Department of Infectious Diseases, Rigshospitalet, Copenhagen University Hospital, Copenhagen, Denmark ${ }^{4}$ Department of Infectious Diseases, Aarhus University Hospital, Aarhus, Denmark

${ }^{5}$ Department of Infectious Diseases, Aalborg University Hospital, Aalborg, Denmark

${ }^{6}$ Department of Infectious

Diseases, Odense

Universitetshospital, Odense, Denmark

Correspondence to

Dr Nina Weis;

nina.weis@regionh.dk

\section{ABSTRACT}

Purpose The purpose of the Danish HIV Birth Cohort (DHBC) is to investigate the significance of HIV-1 infection in pregnancy and after delivery in women living with HIV (WLWH) in Denmark and their children, in the era of antiretroviral therapy and other interventions for treatment and prophylaxis.

Participants All WLWH giving birth to one or more children in Denmark after 31 December 1999 are included, with consecutive ongoing enrolment, if they are living with HIV and pregnant, or if they are diagnosed with HIV in relation to pregnancy, delivery or shortly after delivery. Findings to date $\mathrm{DHBC}$ has been used to describe trends in the management of pregnancies in WLWH and their outcomes on a nationwide basis, mode of delivery and predictors of emergency caesarean section as well as risk factors during pregnancy in WLWH for birth-related complications compared with women from the general population (WGP). We have found that HIV-exposed, but uninfected (HEU) children born to WLWH had a lower median birth weight and gestational age and were at higher risk of intrauterine growth retardation than children born to WGP. We have investigated risk of in-hospital admission and use of antibiotics during the first 4 years of life among HEU children and showed that HEU children had an increased risk of overall hospital admission compared with a matched control group of unexposed children. Further, we compared anthropometric outcomes in children with a matched control group of children not exposed to HIV.

Future plans To continuously investigate the significance of HIV infection and antiretroviral therapy in pregnancy and after delivery in WLWH in Denmark and their HEU children and compare these findings with children born to WGP.

\section{INTRODUCTION}

The management of pregnant women living with HIV (WLWH) has evolved significantly, since the introduction of antiretroviral therapy (ART) for the prevention of perinatal transmission of HIV from mother to child. ${ }^{12}$ Current recommendations include universal testing of pregnant women for HIV infection, immediate initiation of treatment with a combination of two or more antiretroviral drugs from at least two drug classes (combination ART (cART)), the use of caesarean delivery, if the mother has detectable viral load (VL), avoidance of breast feeding when
Strengths and limitations of this study

The Danish HIV Birth Cohort (DHBC) is based on a nationwide, population-based, prospective design including all women living with HIV (WLWH) who give birth in Denmark and their children.

- Use of the unique personal identification number assigned to all Danes allows us to extract data for both the WLWH and their children in national registries.

- Use of national registries ensures prospective, uniformly and neutral data collected on an individual level, restricting the methodological problems of loss to follow-up, selection bias and emigration.

- Linkage to the registries allows identification of a population of controls who are matched on relevant variables.

- The main limitation of the DHBC is the relatively small number of children born to WLWH in Denmark. The DHBC is thus most useful for studies with frequently occurring outcomes.

feasible and post-exposure prophylaxis ART to the child. ${ }^{3-6}$ As cART is now recommended and implemented globally to all people living with HIV, an increasing number of WLWH will either conceive or initiate cART during pregnancy, resulting in a growing population of HIV-exposed, but uninfected (HEU) children ${ }^{7}$ with exposures to HIV and cART in utero which in early life may have potential long-term adverse effects in the children. ${ }^{8}$

The Danish population consists of 5.7 million inhabitants with an estimated adult HIV prevalence of $0.1 \% .{ }^{9}{ }^{10}$ There are approximately 1600 WLWH in Denmark, of whom $80 \%$ are of childbearing age. ${ }^{11} 12$ The majority of WLWH in Denmark are immigrants, mainly from sub-Saharan Africa, and primarily infected with HIV by sexual contact. ${ }^{13}$ We have formerly shown that the majority of WLWH in Denmark have few HIVrelated symptoms, are sexually active and have a strong desire for children. ${ }^{14}$ The healthcare system in Denmark is tax-based and ensures universal access to both medical healthcare and many social support services. ${ }^{15}$ Hence, ART is provided free of charge and people 


\begin{tabular}{|c|c|c|c|}
\hline Domain & Variable & Domain & Variable \\
\hline \multirow{8}{*}{$\begin{array}{l}\text { Maternal } \\
\text { demographics }\end{array}$} & Name & & Vacuum-assistance \\
\hline & & & Scalp lead placement \\
\hline & Date of birth & & Baby heart rate during delivery \\
\hline & Country of birth & & Artificial rupture of membranes \\
\hline & Body mass index prior to pregnancy & & pH umbilical cord \\
\hline & HIV positive date & Child & Date of birth \\
\hline & $\begin{array}{l}\text { Time of diagnosis in relation to } \\
\text { pregnancy }\end{array}$ & & Sex \\
\hline & Transmission route & & Birth weight \\
\hline \multirow{9}{*}{$\begin{array}{l}\text { Maternal medical } \\
\text { history }\end{array}$} & Hepatitis B and/or C infection & & Birth length \\
\hline & & & Head circumference \\
\hline & Comorbidity & & Apgar score \\
\hline & AIDS diagnosis & & Gestational age \\
\hline & CD4 count at diagnosis & & Anaemia at birth \\
\hline & HIV RNA at diagnosis & & First objective clinical examination \\
\hline & Smoking & & ART given to the child \\
\hline & Alcohol use & & Other medications \\
\hline & Drug use & & Breast feeding \\
\hline \multirow[t]{2}{*}{ Family history } & Paternal HIV status & & First HIV PCR result \\
\hline & Other children & & HIV status at 3,6 and 18 months \\
\hline \multirow[t]{3}{*}{ ART treatment } & ART treatment prior to pregnancy & & Transmission of HIV \\
\hline & Initiation of treatment & & \multirow{2}{*}{$\begin{array}{l}\text { Objective clinical examination at } 18 \\
\text { months }\end{array}$} \\
\hline & Change in treatment during pregnancy & & \\
\hline
\end{tabular}

Retrovir during labour $\quad$ ART, antiretroviral therapy.

Continuation of ART after delivery

Other medications during pregnancy

Pregnancy and Estimated date of delivery

delivery

\begin{tabular}{|l}
\hline Planned pregnancy \\
\hline Fertility help \\
\hline Conception \\
Birth plan \\
\hline CD4 count in early pregnancy \\
\hline HIV RNA in early pregnancy \\
Vitamin D in pregnancy \\
\hline Multiple/single birth \\
\hline Intrauterine growth \\
Bleeding during pregnancy \\
Amniocentesis \\
Placenta biopsy \\
Folic acid treatment \\
CD4 count prior to delivery \\
HIV RNA prior to delivery \\
Mode of delivery \\
Complications \\
Pre-eclampsia \\
\hline
\end{tabular}

Continued

living with HIV in Denmark are generally well treated (VL $<50$ copies $/ \mathrm{mL}$ ) with life expectancies approaching those of the general population. ${ }^{16}$ National antenatal screening for all pregnant women has been implemented as an optout programme (eg, all women are screened unless they decline). ${ }^{17}$ The proportion of WLWH that are diagnosed during pregnancy range between $18 \%-37 \%{ }^{13}{ }^{18}$ Treatment with cART has been recommended to all pregnant WLWH in Denmark since the late 1990s and most women have an undetectable VL at the time of delivery, resulting in a decreased risk of perinatal transmission to $<1 \% .{ }^{13} 19$ Condom-less sex (without support from artificial reproductive technologies) and vaginal delivery are recommended in well-treated WLWH. ${ }^{19}{ }^{20}$ New-born treatment with prophylactic antiretroviral medicine lasts for 4 weeks after birth. ${ }^{21} 22$

Children born to WLWH with a HIV RNA $<50$ copies/ $\mathrm{mL}$ are treated with zidovudine for 4 weeks while children born to WLWH with a HIV RNA $>50$ copies/mL are treated with zidovudine, lamivudine and nevirapine for a minimum of 4 weeks.

The Danish HIV Birth Cohort (DHBC) is a nationwide, prospective cohort, set up to monitor the significance of HIV in pregnancy and its outcome in children born to WLWH in Denmark. The cohort was set up by a scientific management team consisting of clinicians and 


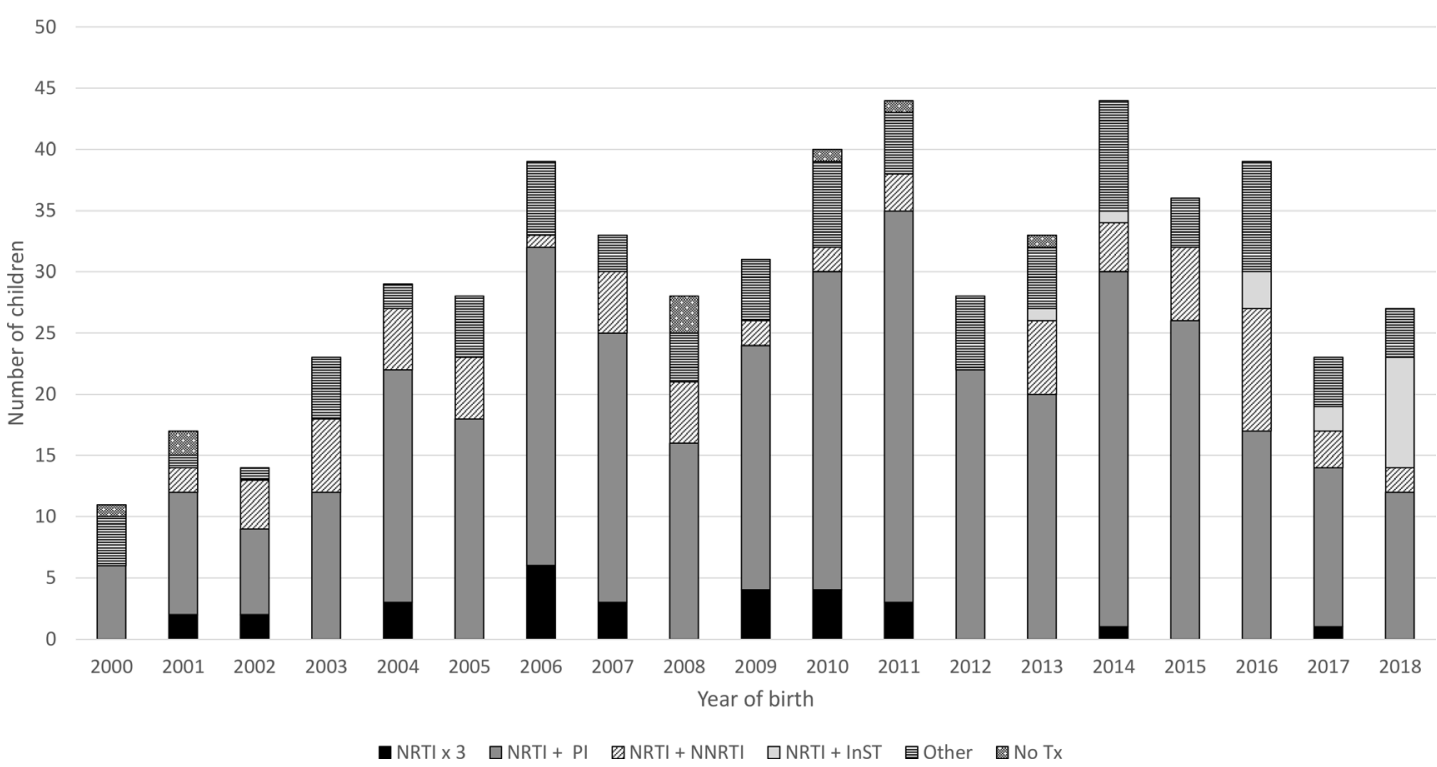

Figure 1 Number of 569 children born to 402 women living with HIV in Denmark and included in the Danish HIV Birth Cohort by year of birth and maternal treatment at delivery. InST, integrase strand transfer inhibitors; NRTI; nuklos(t)ide reverse transcriptase inhibitors; NNRTI, non-nuklos(t)ide reverse transcriptase inhibitors; PI, protease inhibitors; Tx: treatment.

researchers from the five clinical departments of infectious diseases treating pregnant WLWH in Denmark. All five departments are located at University Hospitals in four of the five regions in Denmark. Both treatment of HIV as well as prepartum and postpartum care are done in accordance with national guidelines.

The cohort is located at Copenhagen University Hospital-Hvidovre, Copenhagen, Denmark. The overall aim of the DHBC is to investigate the significance of HIV infection in pregnancy and after delivery in WLWH in Denmark and their children, in the era of antiretroviral therapy and other interventions for treatment and prophylaxis.

The DHBC is approved by the Danish Data Protection Agency (2012-58-0004; AHH-2017-027), the Danish Medical Agency (3-3013-406/4) and Center for Regional Development, Capital Region (R-20049159) as a clinical research database with data registry in a Research Electronic Data Capture (REDCap) system. Individual consent for collection of data for research purposes is provided from all women included in the DHBC. According to Danish Law, approval from the National Committee on Health Research Ethics is not required as no biomedical intervention is performed. The national registries and Statistics Denmark are administered by national authorities.

\section{COHORT DESCRIPTION}

The DHBC is a prospective, nationwide, population-based cohort study including all WLWH giving birth to one or more children in Denmark after 31 December 1999, with consecutive ongoing enrolment. Women are included if they are living with HIV and pregnant, or if they are diagnosed with HIV in relation to pregnancy, delivery or shortly after delivery. Women who are diagnosed with
HIV at a later time point after giving birth, when time of transmission cannot be determined to be prior to or during pregnancy are excluded. Information about miscarriages or stillbirths in WLWH are not included in the cohort. Eligible women are identified and enrolled in the DHBC through the clinical departments by the clinicians responsible for the treatment and management of pregnant WLWH. Hence, the risk that a woman is missed in the DHBC is negligible. The DHBC collects clinical and demographic data on both the mother and the child from the medical records and all data are entered prospectively into a REDCap database. Baseline data are collected the year the child was born. Annual updates are performed.

Baseline data are collected the year the child is born, including maternal demographics, maternal medical history, family history, cART treatment, pregnancy and delivery and among others on the children's date of birth, sex, birth length and birth weight, head circumference, Apgar score, gestational age, ART, other medications, breast feeding and HIV transmission (table 1).

The DHBC includes 569 children born in year 20002018 to 402 WLWH, including seven pairs of twins. The number of children born to WLWH have increased over time (figure 1). The demographics of the cohort are presented in table 2 . The pregnancy was planned in a little more than half the women $(58 \%, \mathrm{n}=330)$, and in 153 pregnancies $(46 \%)$ it was planned together with an infectious disease specialist. One hundred and three (18\%) were diagnosed with HIV during pregnancy, and nine women were diagnosed during birth or shortly afterwards. Information about coinfection with hepatitis $\mathrm{B}$ and C were not available for all WLWH included in DHBC, but of the 402 WLWH, 28 (5\%) were hepatitis B surface Antigen (HBsAg) positive and 129 (23\%) had anti-HBs 
Table 2 Baseline characteristics

\begin{tabular}{lc}
\hline & \multicolumn{1}{l}{ Total } \\
\cline { 2 - 2 } & $\mathbf{n = 5 6 9}$ \\
\hline Maternal characteristics & \\
\hline $\begin{array}{l}\text { Maternal age at birth (mean } \\
(95 \% \text { Cl)) }\end{array}$ & $32.9(32.4$ to 33.4) \\
\hline Missing & 5 \\
Country of origin (n (\%)) & \\
\hline Danish & $130(23)$ \\
\hline African & $327(58)$ \\
\hline Asian & $65(11)$ \\
\hline Other & $47(8)$ \\
Comorbidity (n (\%)) & $144(25)$ \\
\hline Unknown & $35(6)$ \\
\hline Smoking (n (\%)) & $67(12)$ \\
\hline During pregnancy & $28(5)$ \\
\hline Former smoker & $46(8)$ \\
\hline Missing & $209(37)$ \\
\hline Nulliparous (n (\%)) & \\
\hline
\end{tabular}

Time of maternal HIV diagnosis

(n (\%))

\begin{tabular}{|c|c|}
\hline Prior to pregnancy & $457(80)$ \\
\hline During pregnancy & $103(18)$ \\
\hline During/after delivery & $9(2)$ \\
\hline $\begin{array}{l}\text { Duration from diagnosis of HIV } \\
\text { to delivery (years) (n (\%)) }\end{array}$ & $5(1-9)$ \\
\hline \multicolumn{2}{|l|}{ Mode of HIV transmission (n (\%)) } \\
\hline Sexual & $372(65)$ \\
\hline Injection drug use & $17(3)$ \\
\hline Other/missing & $180(32)$ \\
\hline \multicolumn{2}{|l|}{$\begin{array}{l}\text { Antiretroviral therapy treatment } \\
\text { at delivery }(n(\%))\end{array}$} \\
\hline Three NRTIs & $29(5)$ \\
\hline Two NRTIs+NNRTI & $71(12)$ \\
\hline Two NRTIs+PI & $356(62)$ \\
\hline Two NRTIs+InST & $18(3)$ \\
\hline Other & $89(16)$ \\
\hline No treatment prior to delivery & $9(2)$ \\
\hline Intrapartum prophylaxis (n (\%)) & $246(43)$ \\
\hline No intrapartum prophylaxis & $275(49)$ \\
\hline Missing & $48(8)$ \\
\hline \multicolumn{2}{|l|}{ CD4 cell count at delivery (n (\%)) } \\
\hline$>500$ cells $/ \mu \mathrm{L}$ & $268(47)$ \\
\hline $200-499$ cells $/ \mu \mathrm{L}$ & $237(42)$ \\
\hline$<200$ cells $/ \mu \mathrm{L}$ & $25(7)$ \\
\hline Missing & $39(7)$ \\
\hline HIV viral load at delivery $(\mathrm{n}, \%)$ & \\
\hline
\end{tabular}

Continued
Table 2 Continued

\begin{tabular}{|c|c|}
\hline & Total \\
\hline & $\mathrm{n}=569$ \\
\hline$<50$ copies $/ \mathrm{mL}$ & $479(84)$ \\
\hline$\geq 50$ copies $/ m L$ & $62(11)$ \\
\hline Missing & $28(5)$ \\
\hline Child characteristics $\dagger$ & \\
\hline Year of birth (n (\%)) & \\
\hline 2000-2006 & $161(28)$ \\
\hline 2007-2008 & $61(11)$ \\
\hline 2009-2016 & $345(61)$ \\
\hline $\begin{array}{l}\text { Gestational age }<37 \text { weeks ( } \mathrm{n} \\
(\%) \text { ) }\end{array}$ & $52(9)$ \\
\hline Missing & $97(17)$ \\
\hline Mode of delivery (n (\%)) & \\
\hline Vaginal delivery & $211(37)$ \\
\hline Planned caesarean section & $218(38)$ \\
\hline Acute caesarean section & $128(23)$ \\
\hline Missing & $12(2)$ \\
\hline Birth weight, g (mean $(95 \% \mathrm{Cl})$ ) & 3140.7 (3082.7 to 3197.3$)$ \\
\hline Missing & $40(7)$ \\
\hline Birth length, cm (mean (95\%) & 49.9 (49.7 to 50.3$)$ \\
\hline Missing & 75 (13) \\
\hline Child sex (n (\%)) & \\
\hline Boy & $275(48)$ \\
\hline Girl & $261(46)$ \\
\hline Missing & $33(6)$ \\
\hline Apgar score at $10 \mathrm{~min}<7(\mathrm{n}(\%))$ & $8(1)$ \\
\hline Missing & $23(4)$ \\
\hline
\end{tabular}

*Number of HIV-exposed uninfected children born to 402 women living with HIV (WLWH).

†Children born to WLWH with HIV RNA $<50$ copies/mL are treated with zidovudine for 4 weeks while children born to WLWH with HIV RNA $>50$ copies $/ \mathrm{mL}$ are treated with zidovudine, lamivudine and nevirapine for a minimum of 4 weeks.

InST, integrase strand transfer inhibitors; NNRTI, non-nuklos(t) ide reverse transcriptase inhibitors; NRTI, nuklos(t)ide reverse transcriptase inhibitors; PI, protease inhibitors; Tx, treatment.

while 14 (2\%) were hepatitis $\mathrm{C}$ virus (HCV-RNA) positive and $22(4 \%)$ were anti-HCV positive.

Most WLWH were on cART at delivery, with the majority having undetectable VL at the time of delivery. The median gestational age was 39 weeks (IQR 38-40, range 24-40 weeks). Definitive exclusion of HIV infection of the children is based on two negative virological test results prior to or at 18 months of age. Perinatal transmission of HIV occurred in four children. In all these cases, the mother was diagnosed just prior to, during or shortly after delivery, and none of the four women received cART prior to delivery. 

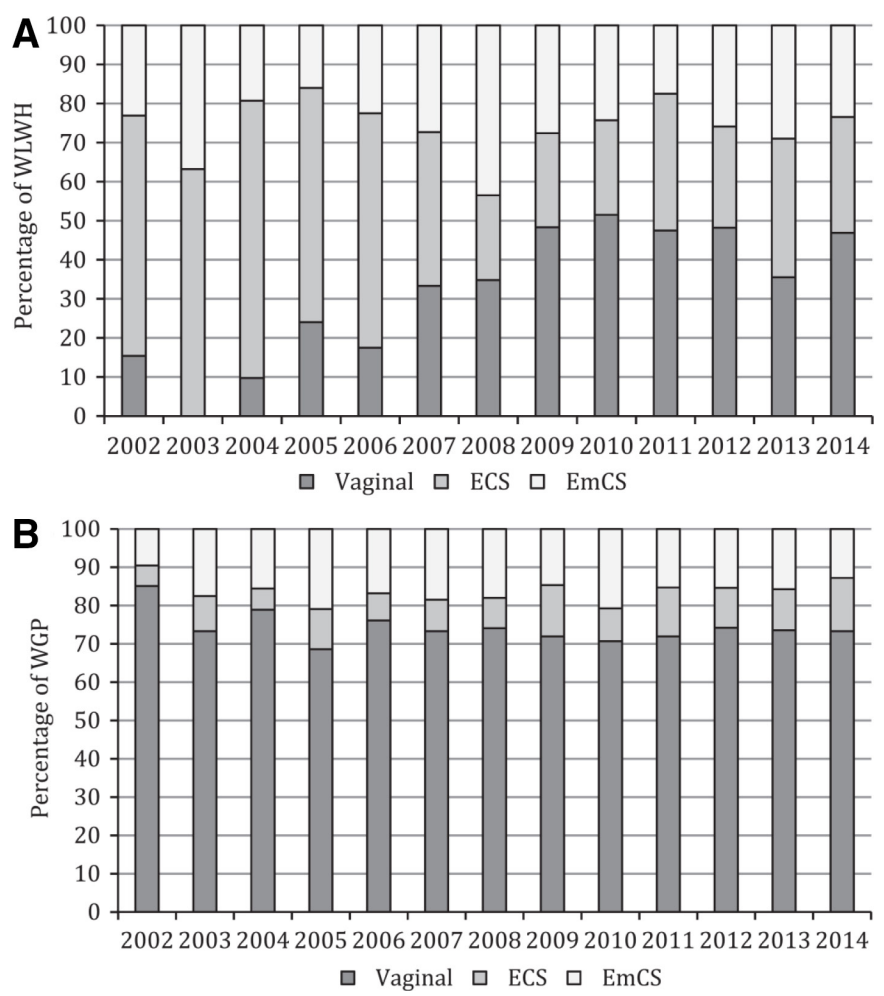

Figure 2 Changes in mode of delivery during 2002-2014 in (A) women living with HIV (WLWH) and (B) women in the general population (WGP) ${ }^{13}$ ECS, elective caesarean section; EmCS, emergency caesarean section.

Using the unique 10-digit personal identification number (PIN), assigned to all Danish residents at birth (or with approved immigration status), the DHBC is linked to the national registries and data from Statistics Denmark containing medical and sociodemographic information on the whole Danish population. ${ }^{23-25}$ This data linkage allows us to capture comparison cohorts, as well as ascertain immigration, emigration and death. ${ }^{23}$

The DHBC has been linked to the following registries: the Medical Birth Registry, which contains complete information on all births in Denmark since $1973^{26}$; the National Patient Registry, which contains information on all inpatient and outpatient hospital admissions in Denmark since $1977^{27}$; the Danish National Prescription Registry, established in 1994 which contains information on all redeemed prescriptions dispensed in Danish Community Pharmacies on an individual level ${ }^{28}$; the Children's Database, which contains all height and weight measurements recorded by medical doctors and nurses during the annual preventive health checks offered to all Danish children until school year $7,^{29}$ and the sociodemographic registries at Statistics Denmark. Data from the national registries and Statistics Denmark are anonymised and accessed through a remote connection to a server at Statistics Denmark. ${ }^{25}$

\section{Patient and public involvement}

Patients or the public were not involved in the design, conduct, reporting or dissemination plans of our research.
Findings to date

In 2010 DHBC data were used to describe trends in the management of pregnancies in WLWH and their outcomes on a national basis. ${ }^{19}$ The annual number of HIV pregnancies increased significantly during the study period and substantial changes in pregnancy management were seen. No perinatal transmissions occurred in WLWH, who received treatment according to the national guidelines at that time, that is, cART before week 22, intravenous zidovudine (ZDV) during labour, neonatal ZDV for 4-6 weeks and no breastfeeding. ${ }^{19}$

Mode of delivery and predictors of emergency caesarean section (EmCS) in WLWH compared with women from the general population (WGP) was assessed in a paper by Ørbæk et al. ${ }^{13}$ The number of WLWH who had a vaginal delivery increased over time, especially after the change in guidelines in 2007 offering vaginal delivery to WLWH with suppressed VLs. Compared with WGP more WLWH planned and delivered by planned caesarean section and they had a twofold higher risk of EmCS (figure 2). EmCS was predicted by age $>40$, African country of origin, asphyxia, delivery during the evening/night, preterm delivery and premature rupture of the membranes (PROM) ${ }^{13}$ A recent study showed that WLWH had more risk factors during pregnancy, including high body mass index $(>25)$, smoking, prior perinatal deaths, prior caesarean section, viral hepatitis (chronic hepatitis B and C) and psychiatric disorders (DO993B1-5) and a higher risk of postpartum haemorrhage and EmCS than WGP. ${ }^{30}$ The risk of most birth-related complications was similar between the groups. Children born to WLWH had a lower median birth weight and gestational age and were at higher risk of intrauterine growth retardation. ${ }^{30}$

It has been suggested that exposures to HIV and cART in utero may have adverse effects on infant development and growth. ${ }^{31-33}$ Using DHBC data, we compared anthropometric outcomes in HEU children with a matched control group of children not exposed to HIV. ${ }^{34} \mathrm{HEU}$ children were smaller (defined as weight-for-age $z$-score) and shorter (defined as length-for-age z-score) at birth, but this difference decreased with time and there was no significant difference between the groups at $>18$ months of age (figure 3). As the z-score already controls for age, gestational age (for children born $<37$ weeks gestation) and sex, these factors were not further controlled for. The absolute difference in weight and length between HEU and the control group children were relatively small, and was not considered to have a negative effect on the health and well-being of HEU children in early childhood. ${ }^{34}$

It has also been hypothesised that exposure to HIV and/or cART in utero or in the postnatal period may affect the development of the infant's immune and other organ systems, resulting in higher morbidity rates among HEU compared with unexposed children. ${ }^{35-38}$ Our study investigating risk of in-hospital admission and use of antibiotics during the first 4 years of life among HEU children, showed that HEU children had an increased risk of overall hospital admission compared with a matched 

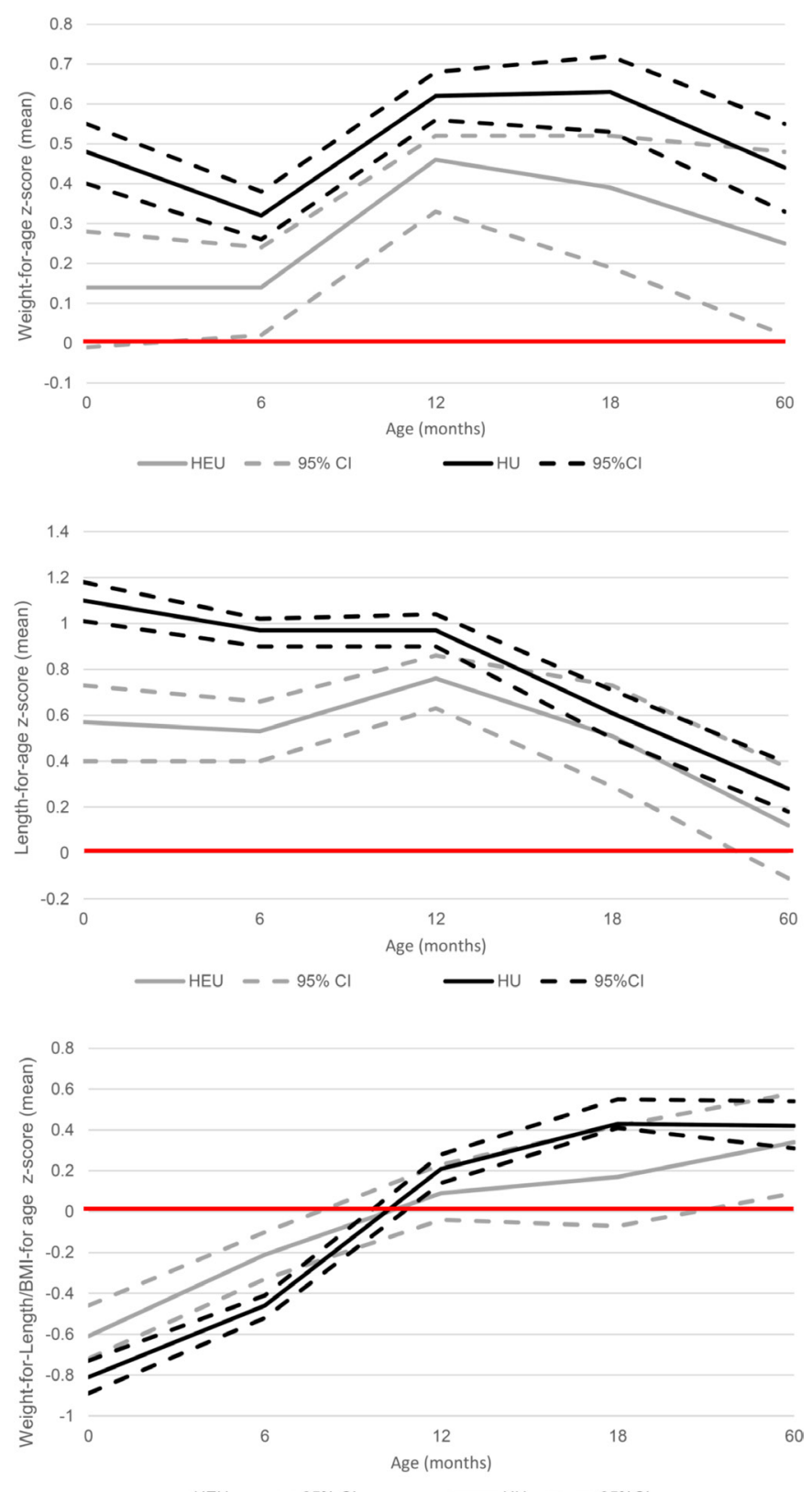

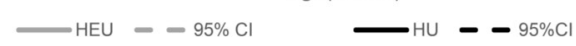

Figure 3 Predicted effect over time of WAZ, LAZ and WLZ/ BMlz z-scores from birth until the age of 5 years from the mixed regression models. ${ }^{34} \mathrm{BMI}$, body mass index; HEU, HIV-exposed, but uninfected; HU, HIV-unexposed; LAZ, length-for-age; WAZ, weight-for-age; WLZ, weight- for-lenght.

control group of unexposed children. This was mainly due to an increased risk of admission due to observation/ non-specific diagnosis, and there was no increased risk of admission due to infectious disease. ${ }^{39}$ Thus, the excess risk of admission among HEU children may be related to prophylactic treatment and/or HIV testing of the infant rather than somatic disease related to HIV and/or cART exposure. $^{39}$

\section{Strengths and limitations}

The main strengths of the DHBC is the nationwide, population-based, prospective design including all WLWH who give birth in Denmark. Use of the unique
PIN assigned to all Danes allows us to extract data for both the WLWH and their children in national registries. The use of registries ensures prospective, uniformly and neutral data collected on an individual level, restricting the methodological problems of loss to follow-up, selection bias and emigration. Moreover, linkage to the registries allow us to identify a population of controls who are matched on relevant variables. The main limitation of the DHBC is the relatively small number of children born to WLWH in Denmark. The DHBC is thus most useful for studies with frequently occurring outcomes.

Contributors NW and EM wrote the manuscript; TLK, M $\emptyset$, MS, GP and ISJ all contributed with data collection and critical revision of the manuscript and NW,

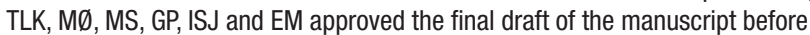
submission.

Funding The authors have not declared a specific grant for this research from any funding agency in the public, commercial or not-for-profit sectors.

Competing interests None declared.

Patient and public involvement Patients and/or the public were not involved in the design, or conduct, or reporting, or dissemination plans of this research.

Patient consent for publication Not required.

Provenance and peer review Not commissioned; externally peer reviewed.

Data availability statement Data are available upon reasonable request. Potential collaborators are welcome to contact the study director Nina Weis (nina.weis@ regionh.dk). Data from the Danish HIV Birth Cohort (DHBC) can be shared with researchers with projects that fall within the overall aim of the DHBC which is to investigate the significance of HIV infection in pregnancy and after delivery in women living with HIV and their children after approval is obtained from the Danish Protection Agency (https://datatilsynet.dk). We encourage collaboration with researchers working with similar data.

Open access This is an open access article distributed in accordance with the Creative Commons Attribution Non Commercial (CC BY-NC 4.0) license, which permits others to distribute, remix, adapt, build upon this work non-commercially, and license their derivative works on different terms, provided the original work is properly cited, appropriate credit is given, any changes made indicated, and the use is non-commercial. See: http://creativecommons.org/licenses/by-nc/4.0/.

\section{ORCID iDs}

Nina Weis http://orcid.org/0000-0002-3133-2724

Mathilde Ørbæk http://orcid.org/0000-0003-0737-8076

Ellen Moseholm http://orcid.org/0000-0002-7195-8641

\section{REFERENCES}

1 Townsend CL, Byrne L, Cortina-Borja M, et al. Earlier initiation of ART and further decline in mother-to-child HIV transmission rates, 2000-2011. AIDS 2014;28:1049-57.

2 Connor EM, Sperling RS, Gelber R, et al. Reduction of maternalinfant transmission of human immunodeficiency virus type 1 with zidovudine treatment. pediatric AIDS clinical Trials Group protocol 076 Study Group. N Engl J Med 1994;331:1173-80.

3 Fowler MG, Qin M, Fiscus SA, et al. Benefits and risks of antiretroviral therapy for perinatal HIV prevention. N Engl J Med 2016;375:1726-37.

4 Kesho Bora Study Group, de Vincenzi I. Triple antiretroviral compared with zidovudine and single-dose nevirapine prophylaxis during pregnancy and breastfeeding for prevention of mother-to-child transmission of HIV-1 (Kesho Bora study): a randomised controlled trial. Lancet Infect Dis 2011;11:171-80.

5 World Health Organisation. Consolidated guidelines on the use of antiretroviral drugs for treating and preventing HIV infection: recommendations for a public health approach, 2016. Available: http://www.deslibris.ca/ID/10089566 [Accessed 24 Mar 2019].

6 World Health Organisation. Updated recommendations on firstline and second-line antiretroviral regimens and post-exposure prophylaxis and recommendations on early infant diagnosis of HIV: 
interim guidelines, 2018. Available: https://www.who.int/hiv/pub/ guidelines/ARV2018update/en/ [Accessed 26 Mar 2019].

7 World Health Organisation. Guideline on when to start antiretroviral therapy and on pre-exposure prophylaxis for HIV, 2015. Available: http://apps.who.int/iris/bitstream/10665/186275/1/9789241509565_ eng.pdf

8 Evans C, Jones CE, Prendergast AJ. Hiv-Exposed, uninfected infants: new global challenges in the era of paediatric HIV elimination. Lancet Infect Dis 2016;16:e92-107.

9 Folketal - Danmarks Statistik website. Available: https://www.dst.dk/ $\mathrm{da} /$ Statistik/emner/befolkning-og-valg/befolkning-og-befolkningsf remskrivning/folketal [Accessed 1 Nov 2018].

10 UNAIDS country factsheets, Denmark, 2017. Available: http://www. unaids.org/en/regionscountries/countries/denmark [Accessed 12 Dec 2018].

11 The Danish HIV cohort. National report, 2017. Available: https://www sundhed.dk/content/cms/63/97963 danhiv dhk rapport_2016 3.pd

12 Statens Serum Institut. Hiv - opgørelse over sygdomsforekomst, 2017. Available: https://www.ssi.dk/sygdomme-beredskab-ogforskning/sygdomsovervaagning/h/hiv-2017 [Accessed 6 Feb 2020].

13 Ørbaek M, Thorsteinsson K, Helleberg M, et al. Assessment of mode of delivery and predictors of emergency caesarean section among women living with HIV in a matched-pair setting with women from the general population in Denmark, 2002-2014. HIV Med 2017;18:736-47.

14 Wessman M, Aho I, Thorsteinsson K, et al. Perception of sexuality and fertility in women living with HIV: a questionnaire study from two Nordic countries. J Int AIDS Soc 2015;18:19962.

15 Tynkkynen L-K, Alexandersen N, Kaarbøe O, et al. Development of voluntary private health insurance in Nordic countries - An exploratory study on country-specific contextual factors. Health Policy 2018;122:485-92.

16 Obel N, Omland LH, Kronborg G, et al. Impact of non-HIV and HIV risk factors on survival in HIV-infected patients on HAART: a population-based nationwide cohort study. PLoS One 2011;6:e22698.

17 Sundhedsstyrelsen [Ministry of Health]. Vejledning Om generel screening AF gravide for infektion Med hepatitis B virus, human immundefekt virus (HIV) OG syfilis, 2010. Available: https://www. sst.dk/ /media/36E8C229A5D54471B775A48F9D2F9333.ashx [Accessed 29 Oct 2019].

18 Hvass A, Christiansen A, Cowan S. Screening af gravide for hepatitis $B$, hiv og syfilis, 2018 [Screening in pregnancy for hepatitis $B$, HIV and syfilis]. EPI-NYT. Available: https://www.ssi.dk/aktuelt/ nyhedsbreve/epi-nyt/2019/uge-21-2019 [Accessed 29 Oct 2019].

19 von Linstow ML, Rosenfeldt V, Lebech AM, et al. Prevention of mother-to-child transmission of HIV in Denmark, 1994-2008. HIV Med 2010;11:448-56.

20 Townsend CL, Byrne L, Cortina-Borja M, et al. Earlier initiation of ART and further decline in mother-to-child HIV transmission rates, 20002011. AIDS 2014;28:1049-57.

21 Danish national Society of Infectious Diseases. HIV-behandling af gravide [HIV-treatment in pregnancy], 2018. Available: http://www. infmed.dk/download?UID=478f0265f6ea7159f22dc2bc6f468be4 ca41c95b [Accessed 24 Jan 2019].
22 Danish Paediatric Society. Children born to women living with HIV. guidelines, 2019. Available: http://paediatri.dk/images/dokumenter/ Retningslinjer_2019/Boern_foedt_af_HIV_positive.pdf [Accessed 6 Feb 2020].

23 Pedersen CB. The Danish civil registration system. Scand J Public Health 2011;39:22-5.

24 Thygesen LC, Ersbøll AK. When the entire population is the sample: strengths and limitations in register-based epidemiology. Eur $J$ Epidemiol 2014;29:551-8.

25 Frank L. Epidemiology. when an entire country is a cohort. Science 2000;287:2398-9.

26 Bliddal M, Broe A, Pottegård A, et al. The Danish medical birth register. Eur J Epidemiol 2018;33:27-36.

27 Lynge E, Sandegaard JL, Rebolj M. The Danish national patient register. Scand J Public Health 2011;39:30-3.

28 Kildemoes HW, Sørensen HT, Hallas J. The Danish national prescription registry. Scand J Public Health 2011;39:38-41.

29 Den Nationale Børnedatabase (BDB) - Sundhedsdatastyrelsen. Available: https://sundhedsdatastyrelsen.dk/da/registre-og-services/ om-de-nationale-sundhedsregistre/graviditet-foedsler-og-boern/ boernedatabasen [Accessed 28 Nov 2018].

30 Ørbaek M, Thorsteinsson K, Moseholm Larsen E, et al. Risk factors during pregnancy and birth-related complications in HIV-positive versus HIV-negative women in Denmark, 2002-2014. HIV Med 2020;21:84-95.

31 Isanaka S, Duggan C, Fawzi WW. Patterns of postnatal growth in HIV-infected and HIV-exposed children. Nutr Rev 2009;67:343-59.

32 Van Dyke RB, Chadwick EG, Hazra R, et al. The PHACS SMARTT study: assessment of the safety of in utero exposure to antiretroviral drugs. Front Immunol 2016;7:199.

33 Powis KM, Smeaton L, Hughes MD, et al. In-Utero triple antiretroviral exposure associated with decreased growth among HIV-exposed uninfected infants in Botswana. AIDS 2016;30:211-20.

34 Moseholm E, Helleberg M, Sandholdt H. Children exposed or unexposed to HIV: weight, height and BMI during the first five years of life. A Danish nationwide cohort study. Clin Infect Dis 2019. [Epub ahead of print: epub ahead of print].

35 Sugandhi N, Rodrigues J, Kim M, et al. HIV-Exposed infants: rethinking care for a lifelong condition. AIDS 2013;27 Suppl 2:S187-95.

36 Taron-Brocard C, Le Chenadec J, Faye A, et al. Increased risk of serious bacterial infections due to maternal immunosuppression in HIV-exposed uninfected infants in a European country. Clin Infect Dis 2014;59:1332-45.

37 Mussi-Pinhata MM, Freimanis L, Yamamoto AY, et al. Infectious disease morbidity among young HIV-1-exposed but uninfected infants in Latin American and Caribbean countries: the National Institute of child health and human development international site development initiative perinatal study. Pediatrics 2007;119:e694-704.

38 Afran L, Garcia Knight M, Nduati E, et al. HIV-Exposed uninfected children: a growing population with a vulnerable immune system? Clin Exp Immunol 2014;176:11-22.

39 Moseholm E, Helleberg M, Nordly SB, et al. Hospital admission among HIV-exposed uninfected children compared with HIVunexposed children. AIDS 2016;30:2697-706. 